\title{
ResearchArticle
}

\section{Performance of soybean [Glycine max (L.) Merrill] varieties to levels of fertility and vermicompost under agro-climatic conditions of vindhyan plateau}

\author{
Raju Jatav and Hansraj Jatav
}

\begin{abstract}
SUMMARY
The present experiment was laid out in the field number 31 of the Research Farm, R.A.K. College of Agriculture, Sehore. The experiment was laid out in split plot design with 18 treatments and each treatment was replicated three times. The observations on plant population per square meter were recorded at 30 days after sowing and at maturity. The effect of varieties was found significant and levels of fertility and vermicompost was found non-significant. Plant population per square meter at 30 DAS was ranged from 45.18 to 59.60 plants, but at maturity it was ranged from 45.12 to 58.13 plants due to effect of varieties. Plant population per square meter at 30 DAS was ranged from 54.33 to 54.64 plants, but at maturity it was ranged from 53.41 to 53.91 plants due to effect of fertility levels although it was found non-significant. The effect of vermicompost on plant population per square meter was also found non-significant, but vermicompost @ 5t/ha was given maximum plants per square meter at both $30 \mathrm{DAS}$ (54.49 plants/sq. meter) and at maturity stages (53.70 plants/sq meter). Varieties had given significant effect on height of plant. Among varieties, JS 93-05 had given significantly tallest plant $(46.11 \mathrm{~cm})$ than JS $335(43.71 \mathrm{~cm})$ and JS $95-60(41.05 \mathrm{~cm})$. Levels of fertility had given non-significant effect on plants height. Although, higher level of fertility $\left(20 \mathrm{~N}+60 \mathrm{P}_{2} \mathrm{O}_{5}+20 \mathrm{~K}_{2} \mathrm{O} \mathrm{kg} / \mathrm{ha}\right)$ had given tallest plants $(43.87 \mathrm{~cm})$ than rest of the levels. Levels of vermicompost had also given significant effect on height of plants. Although, Vermicompost @ $5 \mathrm{t} / \mathrm{ha}$ had given tallest plants $(44.25 \mathrm{~cm})$ than control.
\end{abstract}

Key Words : Soybean, Vermicompost, Variety, Fertility level, Plant population

How to cite this article : Jatav, Raju and Jatav, Hansraj (2020). Performance of soybean [Glycine max (L.) Merrill] varieties to levels of fertility and vermicompost under agro-climatic conditions of vindhyan plateau. Internat. J. Plant Sci., 15 (1): 16-23, DOI: 10.15740/ HAS/IJPS/15.1/16-23, Copyright@ 2020: Hind Agri-Horticultural Society.

Article chronicle : Received : 20.07.2019; Revised : 03.12.2019; Accepted : 18.12.2019

\section{MEMBERS OF THE RESEARCH FORUM}

Author to be contacted :

Raju Jatav, R.A.K. Collage of Agriculture (RVSKVV), Sehore (M.P.)

India

Address of the Co-authors:

Hansraj Jatav, Krishi Vigyan Kendra (RVSKVV), Ujjain (M.P.) India

Email : raj.hans14@gmail.com 